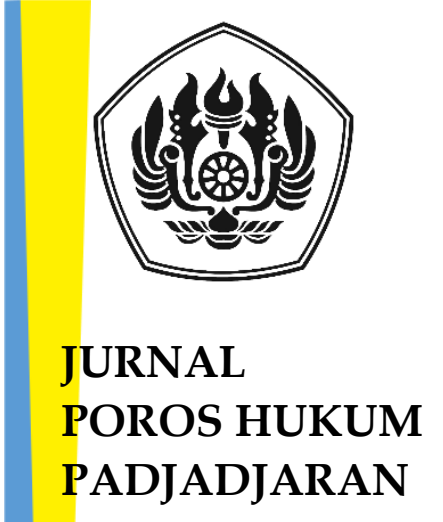

P-ISSN: 2715-7202

E-ISSN: 2715-9418

Artikel diterbitkan: 30 November 2020

DOI:

https://doi.org/10.23920/jphp .v2i1.258

Halaman Publikasi:

http://jurnal.fh.unpad.ac.id/i ndex.php/JPHP/issue/archive

Diterbitkan oleh:

Fakultas Hukum

Universitas Padjadjaran

\section{PERLINDUNGAN HUKUM HAK CIPTA TERHADAP LOGO INSTANSI PEMERINTAH DIHUBUNGKAN DENGAN PRINSIP ALTER EGO}

\section{COPYRIGHT LAW PROTECTION OF GOVERNMENT AGENCY EMPLOYEES AS CREATOR OF GOVERNMENT PROGRAM LOGO ASSOCIATED WITH ALTER EGO PRINCIPLE}

\author{
Mahadiena Fatmasharaa; Muhamad Amirulloh ${ }^{\text {b; }}$ Laina Rafiantic
}

\begin{abstract}
ABSTRAK
Salah satu instansi pemerintah di Jawa Barat, menggunakan logo yang diciptakan oleh pegawai dari instansi tersebut. Pembuatan logo tidak diperjanjikan khusus, sehingga pencipta tidak mendapatkan royalti (materiil dan ekonomi). Hal tersebut menarik untuk dikaji mengenai implementasi prinsip alter ego yang berkaitan pada hak cipta seseorang yang mengakui pencipta sebagai pemilik hak tertinggi. Pencipta memiliki hak alamiah untuk memanfaatkan ciptaannya dan mempertahankan ciptaannya terhadap gangguan apapun dari pihak lain. Metode penelitian yang digunakan dalam penulisan ini bersifat deskriptif analitis guna memperoleh gambaran peraturan perundangundangan yang berlaku dikaitkan dengan teori-teori hukum dan praktek pelaksanaan hukum positif. Pendekatan yang digunakan dalam penelitian ini adalah yuridis normatif, dengan cara meneliti bahan pustaka yang disebut data sekunder yang terdiri dari bahan hukum primer, literatur-literatur, artikel-artikel, pendapat dan ajaran para ahli serta implementasinya dalam praktek. Apabila dilihat pada Pasal 35 ayat (1) dan (2) Undang-Undang Nomor 28 Tahun 2014 tentang Hak Cipta tidak terpenuhi. Meskipun instansi pemerintah tidak bertujuan untuk kegiatan komersial. Namun hak moral dan hak ekonomi hakikatnya wajib dilaksanakan sesuai dengan prinsip perlindungan Hak Kekayaan Intelektual. Perlindungan Hukum terhadap pencipta atas logo tetap harus diakui.
\end{abstract}

Kata kunci: alter ego; hak cipta; hak moral; logo; instansi pemerintah.

\footnotetext{
a Magister Ilmu Hukum Fakultas Hukum Universitas Padjadjaran, Jl. Banda No. 42 Bandung, email: mahadienaf@gmail.com

b Fakultas Hukum Universitas Padjadjaran, Jalan Raya Bandung Sumedang KM. 21 Jatinangor, email: muhamad.amirulloh@unpad.ac.id

Fakultas Hukum Universitas Padjadjaran, Jalan Raya Bandung Sumedang KM. 21 Jatinangor, email: laina@unpad.ac.id
} 


\begin{abstract}
One of the government agencies in West Java, using a logo created by employees of the agency. Logo creation is not specifically promised, so creators do not get royalties (material and economic). It is interesting to review the Implementation of alter ego Principles relating to the copyright of a person who recognizes the creator as the owner of the highest right. The Creator has the natural right to utilize his creation and defend his creation against any interference from the other party.

The research methods used in this writing are analytically descriptive to obtain an overview of the prevailing laws and regulations associated with legal theories and the practice of implementing positive laws. The approach used in this study is normative juridical, by examining library materials called secondary data consisting of primary legal materials, literature, articles, opinions, and teachings of experts and their implementation in practice.

If viewed in Article 35 paragraph (1) and (2) of Law No. 28 of 2014 on Copyright is not fulfilled. Although government agencies do not aim for commercial activities. But moral rights and economic rights must essentially be implemented in accordance with the principles of intellectual property protection. Legal protection of creators over logos must still be recognized.
\end{abstract}

Keywords: alter ego; copyright; government agencies; logo; moral rights.

\title{
PENDAHULUAN
}

Logo dapat mencerminkan identitas perusahaan/instansi/badan lainnya sehingga akan dengan mudah dikenal oleh banyak orang. Logo memiliki makna dan filosofi tersendiri yang terkandung didalamnya, logo juga mampu untuk meningkatkan branding sebuah perusahaan/instansi/badan lainnya. Menurut David E. Carter, logo adalah identitas suatu perusahaan dalam bentuk visual yang diaplikasikan dalam berbagai sarana fasilitas dan kegiatan perusahaan sebagai bentuk komunikasi visual. ${ }^{1}$ Logo dapat juga disebut dengan simbol, tanda gambar, merek dagang (trademark) yang berfungsi sebagai lambang identitas diri serta tanda pengenal yang merupakan ciri khas suatu badan. Pada umumnya logo berfungsi sebagai tanda merek suatu produk tertentu, namun pada badan hukum lainnya, termasuk pada instansi pemerintah juga menggunakan logo tersendiri sebagai identitasnya untuk dikenal masyarakat.

Salah satu contoh penggunaan logo sebagai identitas terdapat pada instansi pemerintah yang dibentuk pada program kerja Pemerintah Provinsi Jawa Barat, khususnya pada periode tahun 2018-2023 yang dipimpin oleh Gubernur Jawa Barat, M. Ridwan Kamil menciptakan program-program unggulan dalam masa pemerintahannya. Berbagai macam program kerja yang diwujudkan dengan membentuk suatu instansi pemerintah sebagai penggerak untuk mewujudkan program unggulannya. Hal ini berawal dari cita-cita untuk mewujudkan Jawa Barat menjadi

\footnotetext{
1 Kurniawan, Denny. (2008). Perancangan Logo dan Maskot untuk Mendukung Promosi Wisata Kuliner Malam Warung Tradisional di Surabaya. Jurusan Desain Komunikasi Visual, Fakultas Seni dan Desain. Surabaya: Universitas Kristen Petra. hlm. 39.
} 
Provinsi Digital. Perhatian ini berasal dari permikiran yang menurutnya cukup besar di Jawa Barat, yaitu adanya kesenjangan rural-urban di bidang teknologi.

Hal tersebut melahirkan gagasan pembentukan berbagai tim unggulan (instansi pemerintah) di Jawa Barat, diantaranya seperti Jabar Quick Response, Jabar Saber Hoaks, Jabar Digital Service dan instansi pemerintah lainnya. Instansi pemerintah ini dibentuk untuk melayani kebutuhan masyarakat, diantaranya seperti Jabar Quick Response yang bertugas untuk melayani masyarakat di bidang sosial memberikan bantuan langsung kepada masyarakat; Jabar Saber Hoaks yang bertugas melayani masyarakat di bidang media sosial untuk memberi penjelasan mengenai informasi/kabar berita hoaks yang beredar di masyarakat serta memberikan literasi digital bagi masyarakat agar bijak menggunakan media sosial; Jabar Digital Service bertugas untuk memberikan informasi yang akurat dan efisien berbasis data dan teknologi, merevolusi pemakaian teknologi dalam kehidupan masyarakat dan pemerintahan di Jawa Barat, serta organnisasi pemerintah lainnya.

Sehubungan dengan pembentukan instansi pemerintah tersebut memerlukan identitas diri, yang salah satunya yaitu adanya logo-logo yang membedakan instansi pemerintah yang satu terhadap instansi pemerintah lainnya, yang mana hal ini juga menjadi ciri khas dari suatu instansi pemerintah. Dalam pembuatan logo-logo tersebut diciptakan oleh salah satu pegawai dari instansi pemerintah tersebut, meskipun pegawai tersebut mendapatkan gaji setiap bulan, namun hak-hak yang dapat diperoleh pegawai sebagai pencipta atas pembuatan logo tersebut tidak diperjanjikan lebih lanjut. Hal ini berkaitan dengan Hak Cipta seseorang yang telah menciptakan suatu karya kemudian berkaitan dengan Prinsip alter ego serta perlindungan hak asasi manusia.

Tidak diaturnya hak cipta atas logo instansi pemerintah, berakibat pencipta tidak mendapatkan royalti berupa hak moral dan hak ekonomi yang sebagaimana dimaksud dalam Pasal 34 dan Pasal 35 ayat (2) Undang-Undang Hak Cipta. Hal ini dipandang karena tidak menjadi suatu kewajiban bagi pihak-pihak yang bersangkutan untuk menindaklanjuti perihal hak cipta logo tersebut. Perlindungan hukum terhadap pencipta atas logo tersebut harus diakui dan diimplementasikan sesuai dengan prinsipprinsip dasar hak kekayaan intelektual serta alter ego.

Berdasarkan uraian diatas diperoleh identifikasi masalah, yang pertama yakni bagaimana Bagaimana kepemilikan atas hak cipta logo instansi pemerintah jika dikaitkan dengan prinsip alter ego? Kedua, bagaimana implementasi prinsip alter ego 
terhadap perlindungan kepemilikan karya cipta logo yang dihasilkan oleh pegawai instansi pemerintah dikaitkan dengan Undang-Undang Nomor 28 Tahun 2014 tentang Hak Cipta?

\section{METODE PENELITIAN}

Metode penelitian dalam penelitian ini menggunakan spesifikasi penelitian deskriptif analisis dengan metode yuridis normatif yaitu bersifat memaparkan atau menggambarkan permasalahan-permasalahan yang ada dan memperoleh gambaran (deskripsi) lengkap tentang keadaan hukum yang berlaku di tempat tertentu dan pada saat tertentu. Penulis membandingkan penelitian ini dengan prespektif yang sudah dilakukan, atau peristiwa hukum tertentu yang terjadi dalam masyarakat. Penulis mencari sumber-sumber penelitian kepustakaan secara online, dikarenakan kondisi pandemic pencarian penulis terbatas.

\section{PEMBAHASAN}

\section{Hak Cipta Merupakan Bagian dari Hak Kekayaan Intelektual}

Keberadaan Hak Kekayaan Intelektual dalam hubungan antar manusia merupakan sesuatu yang melekat dalam masyarakat yang mana sifatnya mengikuti dinamika perkembangan masyarakat itu sendiri. Hak Kekayaan Intelektual merupakan hak yang dimiliki oleh setiap orang atas kemampuan intelektual yang dimilikinya, hak tersebut berupa hak moral untuk mendapatkan perlindungan terhadap kepentingan pribadinya dan hak ekonomi untuk memperloeh keuntungan atas karya yang dihasilkannya. ${ }^{2}$ Secara umum Hak Kekayaan Intelektual terbagi dalam dua kategori yaitu Hak Cipta dan Hak Kekayaan Industri. Sedangkan Hak Kekayaan Industri meliputi Merek, Desain Industri, Desain Tata Letak Sirkuit Terpadu, Rahasia Dagang dan Varietas Tanaman.

Awal mula munculnya perlindungan terhadap Hak Cipta di dunia karena adanya penemuan mesin cetak pada tahun 1436 di Eropa, mesin ini mempermudah pencetakan karya-karya tulis dalam jumlah besar. Perkembangan yang pesat ini membuka peluang baru bagi orang-orang untuk menikmati suatu karya tulis. Dalam hal ini pengusaha percetakan pada saat itu meminta pada raja untuk memiliki hak memperbanyak atas

\footnotetext{
2 Djumhana, Ahmad \& R. Djubaedillah. (1993). Hak Milik Intelektual Sejarah, Teori \& Prakteknya di Indonesia, Bandung: P.T. Citra Aditya Bakti, hlm. 51-58
} 
karya-karya tulis yang akan diterbitkan. Hak cipta yang digunakan pertama kali di dunia yaitu Copyright, yang merupakan hak untuk memperbanyak (the right to copy), sebelumnya hak pengarang untuk memperbanyak karyanya tidak begitu diperhatikan, sehingga hanya melindungi kepentingan perusahaan penerbit saja. Statute of Anne pada tahun 1710, merupakan undang-undang hak cipta pertama di dunia yang juga memberikan pengaruh besar dalam sejarah perkembangan dan perlindungan hak cipta di dunia. ${ }^{3}$

Bentuk konsekuensi dari keikutsertaan Indonesia sebagai anggota WTO (World Trade Organization) mengharuskan Indonesia menyesuaikan segala peraturan perundangannya di bidang Hak Kekayaan Intelektual dengan memenuhi standar TRIP's (Trade Related Aspects of Intellectual Property Rights). Dimulai sejak tahun 1997 dan diperbaharui, kemudian pada tahun 2000, tahun 2001 dan terakhir tahun 2016. Hal ini juga sebagai bentuk konsekuensi dari konvensi-konvensi internasional yang telah diratifikasi di bidang Hak Kekayaan Intelektual. Telah disesuaikan dengan mengatur ketentuan-ketentuan yang dituangkan dalam Undang-Undang tentang Hak Cipta, Desain Industri, Desain Tata Letak Sirkuit Terpadu, Rahasia Dagang, Paten, Merek \& Indikasi Geografis. Pada dasarnya Hak atas Kekayaan Intelektual (HaKI) memiliki prinsip-prinsip yang diantaranya yaitu:4

1) Prinsip Ekonomi

Prinsip ekonomi merupakan perlindungan terhadap kemampuan berpikir/intelektual manusia yang telah diwujudkan dalam suatu karya yang memiliki manfaat serta nilai ekonomi yang akan memberikan keuntungan kepada pemilik hak cipta.

2) Prinsip Keadilan

Prinsip keadilan merupakan suatu perlindungan hukum bagi pemilik suatu hasil dari kemampuan intelektual, sehingga pencipta memiliki kekuasaan dalam penggunaan hak atas kekayaan intelektual terhadap karyanya.

3) Prinsip Kebudayaan

\footnotetext{
${ }^{3}$ History of Copyright. (2013). Available online fiom: http://www.historyofcopyright.org/HistoryofCopyright/. [Accessed Oktober 11, 2020]

4 Suparman, Eman. (2018). Renny Supriyatni. Perlindungan Hukum Kekayaan Intelektual Masyarakat Tradisional, Jurnal Pengabdian Kepada Masyarakat. Vol 2 No. 7. Available online from: http://jurnal.unpad.ac.id/pkm/article/viewFile/20287/9765. [Accessed April 30, 2020].
} 
Prinsip kebudayaan merupakan pengembangan dari ilmu pengetahuan, sastra dan seni guna meningkatkan taraf kehidupan serta akan memberikan keuntungan bagi masyarakat, bangsa dan negara.

4) Prinsip Sosial

Prinsip sosial mengatur kepentingan manusia sebagai warga negara, sehingga hak yang telah diberikan oleh hukum atas suatu karya merupakan satu kesatuan yang diberikan perlindungan berdasarkan keseimbangan antara kepentingan individu dan masyarakat/lingkungannya.

Undang-Undang Nomor 28 tahun 2014 tentang Hak Cipta menjelaskan bahwa Hak Cipta adalah hak ekslusif pencipta yang timbul secara otomatis berdasarkan prinsip deklaratif setelah suatu ciptaan diwujudkan dalam bentuk nyata tanpa mengurangi pembatasan sesuai dengan ketentuan peraturan perundang-undangan yang merupakan hak ekslusif yang terdiri atas hak moral dan hak ekonomi.

Hak kekayaan intelektual bertujuan untuk melindungi hak-hak yang melekat pada setiap orang sebagai pencipta. Setiap orang harus memperoleh manfaat serta penghargaan atas hasil dari pikirannya yang diwujudkan dalam suatu karya baik hak ekonomi maupun hak moral. Pengertian hak ekonomi merupakan hak untuk mendapatkan manfaat ekonomi atas karya ciptanya. Selain itu pencipta juga memiliki hak moral yaitu hak yang melekat pada diri pencipta, hak untuk diakui dan dicantumkan namanya yang berarti bahwa suatu karya tersebut adalah ciptaannya. Hak tersebut tidak dapat dihilangkan atau dihapus tanpa alasan apapun, walaupun Hak Cipta telah dialihkan. Hak moral dan hak ekonomi merupakan hal yang tidak terpisahkan dari prinsip alter ego.

\section{Prinsip Alter Ego Dalam Suatu Karya Cipta}

Pada dasarnya alter ego adalah prinsip yang meletakan dasar pengakuan hak ekonomi maupun hak moral dari pencipta yang tidak bisa diganggu gugat kepemilikannya terhadap suatu invensi yang diciptakaannya. Namun, secara umum prinsip alter ego menekankan penghargan tinggi kepada pencipta dengan ciptaannya dan melekat pada diri pencipta. Hak-hak tersebut merupakan hak eksklusif yang diperoleh pencipta. Menurut Eddy Damian, kekayaan intelektual yang timbul dari kemampuan intelektual seseorang adalah bentuk perwujudan dari alter ego seseorang, 
sebagai refleksi dari kepribadiaanya atau perwujudan kualitas rasa, karsa, dan daya nalarnya. ${ }^{5}$

Semakin banyak, maka akan semakin beragam dan semakin berkualitas kekayaan intelektual yang diciptakan seorang pencipta, di satu pihak akan memberikan nilai tambah terhadap martabat (dignity) dan keuntungan-keuntungan materiil (ekonomi) seorang pencipta yang melahirkan suatu kekayaan intelektual bersangkutan serta di lain pihak akan mencerdaskan kehidupan bangsa. ${ }^{6}$ Prinsip alter ego mengakui bahwa antara pencipta (inventor) dengan karyanya merupakan satu kesatuan. Tidak akan ada karya/invensi/paten tanpa adanya inventor. Dengan demikian inventor memiliki hak alamiah atas produk yang dihasilkan oleh mental labour-nya. Suatu karya merupakan hasil intelektual dari pencipta sebagai wujud dari keahliannya dan mempunyai unsur refleksi pribadi (Alter Ego) sang pencipta.)

Tanpa adanya alter ego, maka tidak akan lahir suatu invensi yang dilindungi. ${ }^{7}$ prinsip alter ego berkaitan dengan teori Hukum Alam (Natural Law), teori Hukum Alam yang pertama yang mendasari konsep perlindungan hukum terhadap Kekayaan Intelektual yang merupakan milik manusia yang menciptakan suatu ciptaan tersebut guna melindungi setiap hak yang melekat pada invensinya. ${ }^{8}$

\section{Hak Kepemilikan dalam Hak Cipta dan Hukum Perikatan}

Undang-undang Nomor 28 Tahun 2014 Tentang Hak Cipta mengatur mengenai kepemilikan Hak Cipta untuk menjamin hak-hak bagi pemilik hak cipta atas karya yang dibuatnya. Pada pasal 1 angka 1 Undang-Undang Nomor 28 Tahun 2014 Tentang Hak Cipta, menjelaskan bahwa Hak Cipta adalah hak eksklusif pencipta yang timbul secara otomatis berdasarkan prinsip deklaratif setelah suatu ciptaan diwujudkan dalam bentuk nyata tanpa mengurangi pembatasan sesuai dengan ketentuan peraturan perundangundangan.

\footnotetext{
5 Damian, Eddy. (2005). Hukum Hak Cipta Edisi Kedua Cetakan ke-3, Bandung: Alumni. Hlm. 44

6 Ibid.

7 Amirulloh, Muhamad (ed.), Mendambakan Regulasi Paten Pendorong Kreativitas Karyawan Inventor di Indonesia, Seputar Jabar Online. Accessed online from: http://www.seputarjabar.com/2015/10/mendambakan-regulasi-patenpendorong.html. [Accessed September 5, 2020].

8 Joachim Friedrich, Carl. (2004). Filsafat Hukum Perspektif Historis, Bandung: Nuansa dan Nusamedia. hlm. 25
} 
Hak Ekslusif yang melekat pada Hak Cipta menjadikan Hak Cipta tersebut berbeda dengan Hak Kekayaan Intelektual lainnya. ${ }^{9}$ hak cipta merupakan hak untuk mencegah orang lain untuk mengklaim, menggandakan, mengumumkan atau memperbanyak suatu ciptaan, kecuali dengan mendapatkan izin dari pemilik atau pemegang hak cipta. Sehingga, hak eksklusif hak cipta tidak dapat diganggu gugat. Hak eksklusif pada Hak Cipta meliputi hak ekonomi dan hak moral. Hak Ekonomi adalah hak untuk mendapatkan manfaat ekonomi dari hasil karya tersebut dan Hak moral adalah hak yang melekat pada pemilik Hak Cipta tersebut berupa hak atas keutuhan karyanya serta hak namanya tetap dicantumkan sebagai pencipta. Selanjutnya mengenai kepemilikan hak cipta tercantum dalam Pasal 1 angka 4 Undang-Undang No. 28 Tahun 2014 tentang Hak Cipta menyatakan bahwa Pemegang Hak Cipta adalah Pencipta sebagai pemilik Hak Cipta, pihak yang menerima hak tersebut secara sah dari Pencipta, atau pihak lain yang menerima lebih lanjut hak dari pihak yang menerima hak tersebut secara sah.

Hal tersebut menegaskan bahwa pencipta yang dianggap sebagai pemilik hak cipta atas suatu karyanya. Pada penelitian ini, hubungan antara pegawai dengan instansi pemerintah yaitu adanya ikatan dinas yang mengikat, sehingga terdapat perjanjian kerja antara instansi pemerintah dengan pegawainya yang mengatur mengenai hak-hak dan kewajiban kedua belah pihak tentang kesepakatan kerja. Namun, antara kedua pihak tersebut tidak diatur kesepakatan mengenai pembuatan logo instansi pemerintah. Dilihat dari segi prinsip alter ego perihal logo yang diciptakan pegawai tersebut tetap milik pegawai tersebut, karena ada hak yang melekat berupa hak moral, hak untuk dicantumkan namanya dalam suatu karya cipta, karena karya cipta merupakan wujud dari hasil pemikiran seseorang. Pegawai sebagai pencipta dari suatu karya yang diwujudkan dalam bentuk logo secara otomatis bahwa yang memiliki logo tersebut adalah penciptanya, namun karena adanya ikatan dinas antara pegawai (sebagai pencipta) dengan instansi pemerintah, maka pegawai dapat mengalihkan haknya, namun tanpa menghilangkan hak moral yang melekat didalamnya.

Instansi pemerintah tersebut menjadi pemegang hak cipta atas logo tersebut. Hukum mengakui hak cipta lahir sejak saat ciptaan selesai diwujudkan, pengertian

\footnotetext{
9 Tiara Hapsari, Faiza. (2012). Eksistensi Hak Moral Dalam Hak Cipta di Indonesia. Universitas Diponegoro, Magister Ilmu Hukum. Jilid 41 No. $3 . \quad$ Available online from: https:// ejournal.undip.ac.id/index.php/mmh/article/viewFile/5777/9865. [accessed November 11, 2020].
} 
diwujudkan mengandung makna dapat dibaca, didengar, atau dilihat sesuai dengan bentuk ciptaan. Sebagaimana ditegaskan dalam Pasal 1 angka 3 Undang-Undang No. 28 Tahun 2014 tentang Hak Cipta yang menyatakan bahwa Ciptaan adalah setiap hasil karya cipta di bidang ilmu pengetahuan, seni, dan sastra yang dihasilkan atas inspirasi, kemampuan, pikiran, imajinasi, kecekatan, keterampilan, atau keahlian yang diekspresikan dalam bentuk nyata.

Karakter sebuah ciptaan merupakan refleksi kreativitas pribadi penciptanya, dengan demikian merupakan refleksi hak moral pencipta pula yang tidak boleh diubah, baik karena perubahan, perusakan atau pemotongan ciptaan, maupun tindakan distortif lainnya yang dapat mengganggu pribadi sekaligus hak moral yang melekat pada penciptanya.

\section{Perlindungan Hukum Terhadap Hak Cipta Logo Instansi Pemerintah dengan} Penerapan Prinsip Alter Ego Menurut Undang-Undang Nomor 28 Tahun 2014 tentang Hak Cipta.

Seorang pencipta memiliki peran penting dalam pembuatan logo suatu perusahaan/instansi/badan lainnya. Tidak dipungkiri bahwa suatu karya seni berupa gambar atau design logo juga membutuhkan suatu proses, waktu, inspirasi, pemikiran, dana, dan kerja keras. Pembuatan suatu logo bisa membutuhkan waktu yang beragam, hal ini tergantung pada kreatifitas seseorang dan hal ini bertujuan agar logo tersebut familiar atau lebih mudah dikenal bagi orang banyak. Maka dari itu sangatlah wajar jika suatu karya seni berupa gambar/design logo memiliki nilai ekonomi dan moral bagi pemegang hak ciptanya dan pencipta tersebut untuk mendapatkan manfaat dari karya ciptanya. Pada logo instansi pemerintah yang dikaji, meskipun tujuan dari pembentukan instansi pemerintah bukan untuk kegiatan yang bersifat komersil, namun pembuatan logo digunakan untuk identitas instansi pemerintah., maka pencipta logo tersebut tetap memiliki hak eksklusif berupa hak ekonomi dan hak moral atas karya ciptanya tersebut.

Indonesia memiliki kewajiban untuk menjamin perlindungan hak asasi manusia demi meningkatkan kesejahteraan bagi warga negaranya, sebagaimana tercantum dalam Undang-Undang Dasar 1945 pada Pasal 28 huruf C ayat (1) yang menyatakan bahwa setiap orang berhak mengembangkan diri melalui pemenuhan kebutuhan dasarnya, berhak mendapat pendidikan dan memperoleh manfaat dari ilmu 
pengetahuan dan teknologi, seni dan budaya, demi meningkatkan kualitas hidupnya dan demi kesejahteraan umat manusia. Serta pada Pasal 28 huruf D ayat (1) UndangUndang Dasar 1945 menyatakan bahwa setiap orang berhak atas pengakuan, jaminan, perlindungan, dan kepastian hukum yang adil serta perlakuan yang sama dihadapan hukum.

Dari Pasal 28 huruf C ayat (1) dan Pasal 28 huruf D ayat (1) Undang-Undang Dasar 1945 menunjukkan bahwa pemerintah menjamin setiap orang untuk memiliki hak yang sama dan kesetaraan yang sama pada setiap individu. Pemerintah sebagai wakil negara memiliki kewajiban untuk menjamin kepastian hukum pada setiap individu dan mewujudkan kesejahteraan bagi setiap warga negaranya. Seiring dengan perkembangan ilmu pengetahuan, teknologi, seni, dan sastra, sudah demikian pesat sehingga karya karya yang sudah dibuat oleh pencipta memerlukan pelindungan dan jaminan kepastian hukum bagi pencipta.

Sesuai dengan dibentuknya Undang-Undang Nomor 28 Tahun 2014 Tentang Hak Cipta yaitu betujuan untuk meningkatan pelindungan dan jaminan kepastian hukum bagi Pencipta, Pemegang Hak Cipta, dan Pemilik Hak Terkait dan pandangan hak cipta yang merupakan kekayaan intelektual di bidang ilmu pengetahuan, seni, dan sastra yang mempunyai peranan strategis dalam mendukung pembangunan bangsa dan memajukan kesejahteraan umum sebagaimana diamanatkan oleh Undang-Undang Dasar Negara Republik Indonesia Tahun 1945. Beberapa aturan yang berkaitan dengan perlindungan hukum untuk hak cipta atas logo instansi pemerintah yaitu pada UndangUndang Nomor 28 Tahun 2014 Tentang Hak Cipta yaitu terdapat dalam beberapa pasal, diantaranya Pasal 34 yang menyatakan bahwa dalam hal Ciptaan dirancang oleh seseorang dan diwujudkan serta dikerjakan oleh Orang lain di bawah pimpinan dan pengawasan Orang yang merancang, yang dianggap Pencipta yaitu Orang yang merancang Ciptaan.

Serta pada Pasal 35 ayat (1) Undang-Undang Nomor 28 Tahun 2014 yang menyatakan bahwa kecuali diperjanjikan lain Pemegang Hak Cipta atas Ciptaan yang dibuat oleh Pencipta dalam hubungan dinas, yang dianggap sebagai Pencipta yaitu instansi pemerintah. Selanjutnya pasal 35 ayat (2) Undang-Undang Nomor 28 Tahun 2014 yang menyatakan bahwa dalam hal Ciptaan sebagaimana dimaksud pada ayat (1) digunakan secara komersial, Pencipta dan/atau Pemegang Hak Terkait mendapatkan imbalan dalam bentuk Royalti. Selanjutnya pasal 35 ayat (3) Undang-Undang Nomor 28 
Tahun 2014 menyatakan bahwa Ketentuan lebih lanjut mengenai pemberian Royalti untuk penggunaan secara komersial sebagaimana dimaksud pada ayat (2) diatur dengan Peraturan Pemerintah.

Merujuk pada Pasal 34 Undang-Undang Nomor 28 Tahun 2014 tentang Hak Cipta bahwa pegawai yang memimpin proses penciptaan logo tersebut dinyatakan sebagai pemilik hak cipta. Namun pada Pasal 35 ayat (1) Undang-Undang Nomor 28 Tahun 2014 tentang Hak Cipta secara otomatis memberikan hak kepemilikan kepada instansi pemerintah, berdasarkan prinsip alter ego penciptalah yang secara alamiah seharusnya memiliki hak kepemilikan atas logo tersebut. Selain itu, pada praktiknya Pasal 35 ayat (2) Undang-Undang Nomor 28 Tahun 2014 tentang Hak Cipta tidak terlaksanakan. Meskipun program unggulan Gubernur Jawa Barat tidak bertujuan untuk kegiatan komersial. Pemberian royalti hakikatnya wajib diberikan kepada pencipta sesuai dengan prinsip perlindungan Hak Kekayaan Intelektual.

Apabila dibandingkan dengan program pemerintah lainnya, seperti PON XIX Jabar tahun 2016 diadakan perlombaan untuk logo PON XIX Jabar tahun 2016. Pemenang lomba tersebut memperoleh hadiah sebesar Rp. 50.000.000,00,- (lima puluh juta rupiah), yang mana pemenang sebagai pencipta dari logo tersebut memperoleh royalti berupa hak moril dan hak ekonomi atas logo yang diciptakannya. Hal tersebut sebagai penghargaan bagi pencipta karena telah memberikan manfaat berupa karya cipta logo untuk program Pemerintah Jawa Barat. Program tersebut bukan bertujuan untuk kegiatan komersial, namun instansi pemerintah tetap memberikan royalti kepada pemenang lomba logo PON XIX Jabar tahun 2016.

Suatu karya yang diciptakan oleh pegawai dari instansi pemerintah dalam hal adanya dalam hubungan dinas secara otomatis kepemilikannya beralih kepada instansi pemerintah, sebagaimana yang tercantum pada Pasal 35 Undang-Undang Nomor 28 Tahun 2014 tentang Hak Cipya. Namun, apabila dilihat dari sisi prinsip alter ego dan dasar-dasar hak kekayaan intelektual, hak moral yang melekat pada pencipta tidak dapat beralih, karena suatu karya merupakan hasil dari pemikiran intelektual pencipta. Perlindungan hukum atas karya cipta khususnya pada logo-logo instansi pemerintahan di Indonesia, idealnya mengacu pada penerapan prinsip alter ego dan dasar-dasar hak kekayaan intelektual yang melahirkan hak eksklusif dari suatu ciptaan dan meletakkan dasar pengakuan hak moral maupun hak ekonomi dari pencipta dan dapat 
dipertahankan kepemilikannya terhadap suatu karya yang diciptakannya, sehingga pencipta memiliki hak alamiah untuk memanfaatkan ciptaannya.

Pada dasarnya hak cipta muncul secara otomatis tanpa perlu melalui proses pendaftaran seperti bidang Hak Kekayaan Intelektual lainnya. Prinsip dasar ini berasal dari Konvensi Berne yang mengatur bahwa perlindungan hukum sebuah ciptaan tidak diperoleh karena sebuah pendaftaran melainkan tekah diwujudkan dalam bentuk nyata. Namun, konsep dasar mengenai hak cipta tidak menghalangi pencipta untuk mendaftarkan ciptaannya. Perihal pendaftaran ciptaan bukan merupakan suatu kewajiban, namun dalam praktik pendaftaran ciptaan dapat memberikan manfaat bagi para pencipta, karena dapat dijadikan sebagai bukti bahwa karya cipta tersebut sudah terdaftar dan sebagai alat bukti jika dikemudian hari terjadi sengketa dengan pihak lain. ${ }^{10}$

Sehingga pendaftaran Hak Cipta bukan untuk memperoleh perlindungan Hak Cipta, karena seorang Pencipta yang tidak mendaftarkan Hak Cipta juga telah mendapatkan perlindungan, selama pencipta dapat membuktikan bahwa karya cipta tersebut benar-benar ciptaannya. Namun, pendaftaran bukanlah jaminan mutlak bahwa pendaftar sebagai pencipta yang dilindungi hukum, Undang-undang Hak Cipta tetap melindungi Pencipta, hal ini terlepas dari ia mendaftarkan ciptaanya atau ciptaannya tidak didaftarkan. ${ }^{11}$ Konvensi Berne mengatur mengenai hak-hak moral (droit moral). Hak yang dimaksud ini adalah hak pencipta untuk mengklaim sebagai pencipta suatu ciptaan dan hak pencipta untuk mengajukan keberatan terhadap setiap perbuatan yang bermaksud untuk mengubah, mengurangi atau menambah keaslian ciptaanya yang dapat meragukan kehormatan dan reputasi penciptanya. ${ }^{12}$

Dalam upaya untuk melindungi hak cipta atas logo tersebut, pencipta dapat melakukan tindakan tertentu agar hak ekonomi dan hak moral yang melekat pada ciptaannya dapat terlindungi yaitu dengan cara dibuatnya kesepakatan antara pegawai dengan instansi pemerintah perihal logo tersebut yang mengatur mengenai hak dan kewajiban tertentu, bahwa pegawai selaku pencipta dari logo tersebut dapat

\footnotetext{
${ }^{10}$ Ibid.

${ }^{11}$ Tian Marlionsa, A A Ngr. Ida Ayu Sukihana. (2018). Pelanggaran Hak Atas Kekayaan Intelektual Dan ntutan Ganti Rugi Mengenai Hak Cipta Logo Dari Pencipta. Jurnal Kertha Semaya. Vol. 6 no. 3. Accessed online from: https://ocs.unud.ac.id/index.php/kerthasemaya/article/view/26893. [accessed Agustus 15, 2020].

12 Oksidelfa Yanto. (2016). Konvensi Bern dan Perlindungan Hak Cipta. Jurnal Surya Kencana Dua: Dinamika Masalah Hukum dan Keadilan. Jurnal Universitas Pamulang Vol. 6 No. 1. Accessed online from: https://jdihn.go.id/files/414/341-551-1-SM.pdf. [Accessed November 11,2020]
} 
memberikan "izin" kepada instansi pemerintah agar menjadi pemegang hak cipta atas logo tersebut dan berhak untuk menggunakan logo tersebut sebagai identitas dari instansi pemerintah yang bersangkutan. Hal ini tanpa mengurangi atau meghilangkan hak moral yang melekat pada pencipta logo tersebut, karena melalui suatu perjanjian berdasarkan pemberian hak dengan kesepakatan tertentu antara kedua belah pihak yang bertujuan untuk mengalihkan hak penggunaan karya cipta. Sangatlah wajar apabila pencipta mendapatkan sejumlah imbalan atas karya ciptanya tersebut sebagai bentuk penghargaan (reward) dari instansi pemerintah tersebut, agar pencipta dapat menikmati manfaat dari suatu karya ciptanya.

Selain itu akan lebih baik jika logo tersebut di daftarkan ke Direktoral Jenderal Kekayaan Intelektual, meskipun logo tidak disebutkan dalam Undang-Undang Nomor 28 Tahun 2014 tentang Hak Cipta, namun pandangan penulis logo termasuk gambar yang merupakan wujud dari hasil karya cipta seseorang. Logo yang pada umumnya dihasilkan dalam bentuk gambar, dan gambar termasuk dalam salah satu ciptaan yang dilindungi menurut Undang-Undang Nomor 28 Tahun 2014 tentang Hak Cipta. ${ }^{13}$ Dengan dilakukannya pencatatan, maka sudah tentu memberikan keuntungan yang lebih dibandingkan dengan tidak melakukan pencatatan, keuntungan yang diperoleh adalah kemudahan dalam proses pembuktian Hak Cipta apabila timbul sangketa dikemudian hari. Hak cipta terhadap logo tetap mendapat perlindungan walaupun tidak dilakukan pencatatan selama pencipta dapat membuktikan bahwa logo tersebut merupakan hasil ciptaannya, yang dapat dilihat dari tanggal pembuatan dan publikasinya.

Apabila logo belum pernah dipublikasikan atau diumumkan, syarat minimal pembuktian dapat dibuktikan dengan adanya pihak lain yang melihat pencipta membuat karya ciptanya. Pihak tersebut merupakan saksi sebagai bukti keaslian ciptaan selain melalui pencatatan ciptaan. ${ }^{14}$ Pencatatan tersebut merupakan upaya antisipasi terhadap perbuatan-perbuatan pelanggaran atas Logo yang dilakukan tanpa izin dan

\footnotetext{
${ }^{13}$ Risa Amrikasari. (2016) Prosedur Pendaftaran Logo Perusahaan. Hukumonline.com. accessed online from: https:// www.hukumonline.com/klinik/detail/ulasan/lt577c8450a6db6/prosedur-pendaftaran-logo-perusahaan/ [Acessed November 12, 2020].

${ }^{14}$ Arfan, Hidayat. Dahlan. (2014). Perlindungan Hak Cipta Logo Berdasarkan Undang-Undang Republik Indonesia Nomor 28 Tahun 2014 tentang Hak Cipta. Jurnal Ilmiah Mahasiswa Bidang Hukum Keperdataan. Universitas Syiah Kuala. Vol. 1(2) November 2017.
} 
sepengetahuan pencipta. Kekuatan hukum Hak cipta atas Logo akan lebih kuat pembuktiannya apabila dengan dilakukannya pencatatan. ${ }^{15}$

Penulis melihat logo instansi pemerintah tidak termasuk dalam Hak Merek, hal ini karena penulis melihat instansi pemerintah tersebut merupakan program pemerintah yang tujuannya untuk pelayanan masyarakat (public service) dan instansi pemerintah tidak bertujuan untuk kegiatan perdagangan barang/jasa. Namun logo dibutuhkan instansi pemerintah guna sebagai identitasnya serta menjadi pembeda dengan instansi-instansi lainnya. Hal ini dipandang berdasarkan Pasal 1 huruf 1 Undang-Undang Nomor 20 Tahun 2016 tentang Merek dan Indikasi Geografis bahwa logo adalah bagian dari merek guna membedakan barang/jasa yang diproduksi orang atau badan hukum dalam kegiatan perdagangan barang/jasa.

\section{Implementasi Prinsip Alter Ego Pembuat Logo Dikaitkan dengan Undang-Undang Nomor 28 Tahun 2014 tentang Hak Cipta}

Design logo suatu perusahaan/instansi/badan lainnya merupakan salah satu objek hak cipta yang dilindungi berdasarkan Pasal 40 ayat (1) huruf (f) Undang-Undang Nomor 28 Tahun 2014 Tentang Hak Cipta yakni karya seni rupa dalam segala bentuk seperti lukisan, gambar, ukiran, kaligrafi, seni pahat, patung, atau kolase, yang mana logo pada instansi pemerintah yang diteliti merupakan gambar digital. Dalam penjelasannya karya seni rupa dalam segala bentuk seperti gambar diartikan sebagai satu kesatuan yang utuh yang merupakan satu kesatuan karya cipta, meskipun logo tersebut diartikan sebagai gambar yang dibuat secara digital, menggunakan aplikasi tertentu didalam computer, laptop dan alat elektronik lainnya.

Dalam Undang-Undang Nomor 28 Tahun 2014 tentang Hak Cipta menyatakan bahwa hak cipta merupakan hak ekslusif yang terdiri atas Hak Moral dan Hak Ekonomi sebagai dasar untuk memanfaatkan ciptaannya. Lebih lanjut dalam penjelasan Pasal 4 Undang-Undang Nomor 28 Tahun 2014 tentang Hak Cipta menjelaskan bahwa hak ekslusif adalah hak yang hanya diperuntukkan bagi Pencipta, sehingga tidak ada pihak lain yang dapat memanfaatkan hak tersebut tanpa izin Pencipta. Hal tersebut berarti bahwa hukum positif di Indonesia memberikan penghargaan tertinggi kepada pencipta 
dan memberikan hak bagi pencipta untuk mempertahankan karya ciptaannya dari gangguan pihak lain yang beritikad tidak baik terhadap ciptaannya.

Pengertian prinsip alter ego adalah prinsip yang meletakkan dasar pengakuan ekonomi maupun hak moral dari pencipta, sehingga pencipta mempunyai hak alamiah untuk memanfaatkan ciptaannya. Pada hakikatrnya prinsip alter ego adalah prinsip yang meletakkan dasar pengakuan ekonomi maupun hak moral dari pencipta, dan tidak bisa diganggu gugat kepemilikannya terhadap suatu invensi yang diciptakaannya, namun secara umum prinsip alter ego menekankan penghargan yang tinggi kepada pencipta dengan ciptaannya dan melekat pada diri pencipta.

Selanjutnya, menurut Eddy Damian yang mengemukan pendapatnya bahwa kekayaan intelektual yang timbul dari kemampuan intelektual seseorang, adalah tiada lain dari bentuk perwujudan alter egonya (refleksi kepribadiaanya) atau perwujudan kualitas rasa, karsa, dan daya nalarnya. Semakin banyak, semakin beragam dan semakin berkualitas kekayaan intelektual yang diciptakan seorang pencipta, di satu pihak akan memberikan nilai tambah terhadap martabat (dignity) dan keuntungan-keuntungan materiil atau ekonomi seorang pencipta yang melahirkan suatu kekayaan intelektual bersangkutan, dan di lain pihak akan mencerdaskan kehidupan bangsa pada umumnya. ${ }^{16}$

Dari penjelasan prinsip alter ego tersebut terlihat bahwa hak moral adalah hak yang dimiliki pencipta dan melekat pada diri pencipta. Hak moral dan hak ekonomi dijamin oleh sistem hukum yang berlaku, baik secara nasional maupun internasional. Sistem hukum tersebut memberikan pengakuan dan perlindungan atas karya cipta dalam karya seni sebagai bentuk kreativitas pencipta. Secara filosofi pemberian royalti diberikan kepada seseorang, bukanlah merupakan biaya untuk melaksanakan kembali suatu kegiatan, tetapi merupakan bentuk penghargaan (reward) terhadap seseorang yang telah menghasilkan suatu karya cipta. Prinsip alter ego didasarkan pada aliran hukum alam berkembang pesat yang menyatakan bahwa suatu karya cipta adalah perwujudan tertinggi (alter ego) dari pencipta dan pencipta mempunyai hak alamiah untuk memanfaatkan ciptaannya. Konsep ini berkembang pesat setelah revolusi

${ }^{16}$ Damian, Eddy. (2015). Hukum Hak Cipta Edisi Kedua Cetakan ke-3, Bandung: Alumni. hlm. 44. 
Perancis tahun 1789, konsep ini meletakkan dasar pengakuan tidak saja hak ekonomi dari pencipta namun juga termasuk hak moral. ${ }^{17}$

Namun pada prakteknya, pembuatan logo instansi pemerintah tersebut tidak mengatur kesepakatan lebih lanjut mengenai hak-hak yang dapat diperoleh oleh pencipta logo dengan instansi pemerintah. Hal tesebut karena pembuatan logo tersebut dianggap juga menjadi tugas dari pegawai instansi pemerintah tersebut, menurut pasal 35 Undang-Undang No. 28 Tahun 2014 tentang Hak Cipta sehingga kepemilikan atas logo instansi tersebut, meskipun dalam bawah ikatan dinas dengan suatu instansi pemerintah, namun prinsip alter ego melekat pada pencipta design logo tersebut yang mana hak cipta atas design logo tersebut melekat pada pencipta yaitu pegawai instansi pemerintah tersebut.

Prinsip alter ego yang meletakkan dasar pengakuan hak moral maupun pemanfaatan hak ekonomi dari pencipta, sehingga pencipta memiliki hak alamiah untuk memanfaatkan ciptaannya dan mempertahankan ciptaannya terhadap gangguan apapun dari pihak lain. Hak Ekslusif yang melekat pada hak cipta sebagai bentuk alter ego pencipta yang menekankan penghargaan tertinggi terhadap pencipta dengan ciptaannya dan melekat pada diri pencipta sehingga hak yang melekat pada hak cipta dapat dipertahankan terhadap apapun juga, berdasarkan prinsip ini maka sudah seharusnya pemanfaatan ataupun penggunaan suatu karya cipta design logo haruslah terlindungi hak-hak dari pencipta atau pemegang hak cipta design logo tersebut, hal ini guna terjaminnya kepastian hukum agar tidak sembarangan pihak dapat memakai logo instansi pemerintah, harus ada izinnya terlebih dahulu dari pencipta atau pemegang hak cipta design logo tersebut.

\section{PENUTUP}

\section{Kesimpulan}

Berdasarkan pembahasan diatas, maka diperoleh kesimpulan yaitu perlindungan hukum terhadap pencipta atas logo instansi pemerintah sebenarnya sudah secara otomatis terlindungi oleh Undang-Undang Nomor 28 Tahun 2014 tentang Hak Cipta pada Pasal 1 huruf 1. Munculnya perlindungan suatu karya cipta dimulai sejak ciptaan itu nyata. Hal ini menjadi dasar bahwa suatu ciptaan baik yang tercatat maupun tidak

\footnotetext{
${ }^{17}$ Djumhana, M. dan R. Djubaedilah. (1993). Hak Kekayaan Intelektual (Sejarah, Teori dan Praktik) di Indonesia, Bandung: Citra Aditya Bakti. hlm. 38 .
} 
tercatat tetap dilindungi Hak Ciptanya. Namun guna melindungi hak cipta atas logo instansi pemerintah, pencipta dapat melakukan upaya pencegahan, yaitu memberikan “izin" terhadap pihak yang akan menggunakan logo tersebut, hal ini dapat melalui suatu perjanjian antara instansi pemerintah dengan pegawai (sebagai pencipta) yang mengatur beberapa ketentuan-ketentuan yang disepakati terhadap logo tersebut.

Selain itu, pencipta dapat melakukan upaya pencatatan ciptaan, pencatatan ini sudah tentu memberikan keuntungan yang lebih dibandingkan dengan tidak melakukan pencatatan. Keuntungan yang diperoleh adalah kemudahan dalam proses pembuktian Hak Cipta apabila timbul sangketa dikemudian hari. Upaya secara represif juga dapat ditempuh melalui jalur litigasi sebagai ultimum remidium yaitu melalui penyelesaian sengketa arbitrase, gugatan ganti rugi melalui pengadilan, dan tuntutan pidana yang diajukan melalui pengadilan negeri apabila pencipta merasa adanya kerugian atas logo tersebut yang diakibatkan oleh pihak lain.

Implementasi prinsip alter ego yang mengakui Pencipta sebagai pemilik hak tertinggi, yang meletakan dasar pengakuan hak moral maupun pemanfaatan hak ekonomi dari pencipta, sehingga pencipta memiliki hak alamiah untuk memanfaatkan ciptaannya dan mempertahankan ciptaannya terhadap gangguan apapun dari pihak lain. Namun pembuatan logo instansi pemerintah tersebut belum diatur kesepakatannya lebih lanjut mengenai hak-hak yang dapat diperoleh pegawai selaku pencipta dengan instansi pemerintah terkait, karena anggapan bahwa pembuatan logo menjadi tugas dari pegawai instansi pemerintah dan berada dibawah ikatan dinas dengan suatu instansi pemerintah, namun penulis melihat bahwa pembuatan logo instansi pemerintah tetap harus diimplementasikan sesuai dengan prinsip alter ego yang melekat pada pencipta logo tersebut. Pencipta berhak untuk mencantumkan namanya pada logo tersebut, karena hak eksklusif atas logo tersebut melekat pada pencipta dan tidak bisa diganggu gugat.

\section{Saran}


Dalam hal instansi yang membutuhkan jasa pembuatan logo untuk identitas suatu instansi pemerintah yang dibawahinya, alangkah lebih baik untuk melakukan Pengadaan Jasa Lainnya berupa Pekerjaan Pembuatan Logo pada instansi terkait yang sebagaimana diatur dalam Peraturan Pemerintah Nomor Nomor 16 Tahun 2018 Tentang Pengadaan Barang/Jasa Pemerintah. Hal ini agar terciptanya kepastian hukum untuk suatu pekerjaan yang tidak bersifat rutin, sehingga pekerjaan dari pencipta dari logo tersebut lebih jelas dan tidak bercampur dengan pekerjaan lainnya. Dengan menempuh proses tersebut, kesepakatan yang dituangkan dalam perjanjian antara pencipta dengan suatu instansi pemerintah tersebut, dapat lebih menjamin kepastian hukum. Disatu sisi pencipta dari logo tersebut dapat memperoleh keuntungan berupa hak moral (pengakuan atas karya cipta logo) pencipta dari logo tersebut tetap diakui sebagai pencipta dan instansi pemerintah sebagai pemegang hak cipta yang mana hal ini merupakan wujud dari suatu "izin" dari pencipta bahwa logo tersebut berhak digunakan oleh instansi pemerintah tersebut. Maupun hak ekonomi (penghargaan atas karya cipta berupa sejumlah uang yang disepakati para pihak sebagai bentuk reward atau penghargaan atas karya ciptanya).

Menurut pandangan penulis, akan lebih baik jika logo tersebut di daftarkan ke Direktoral Jenderal Kekayaan Intelektual, meskipun logo tidak disebutkan dalam Undang-Undang Nomor 28 Tahun 2014 tentang Hak Cipta, namun pandangan penulis logo termasuk gambar yang merupakan wujud dari hasil karya cipta seseorang. Logo instansi pemerintah memiliki pengertian yang berbeda dengan Hak Merek, karena tujuan pembentukan logo instansi pemerintah yaitu untuk public service, bukan untuk kegiatan perdagangan barang/jasa. Sedangkan menurut Pasal 1 huruf 1 UndangUndang Nomor 20 Tahun 2016 tentang Merek dan Indikasi Geografis yang menyatakan bahwa logo adalah bagian dari merek guna membedakan barang/jasa yang diproduksi orang atau badan hukum dalam kegiatan perdagangan barang/jasa. Meskipun logo tidak dilindungi oleh hak cipta sebagaimana diatur dalam Pasal 65 Undang-Undang Nomor 28 Tahun 2014 tentang Hak Cipta. Namun, logo akan tetap mendapatkan perlindungan Hak Cipta, pencatatan Hak Cipta bukanlah persyaratan untuk mendapatkan perlindungan atas Hak Cipta yang sebagaimana tertuang dalam Pasal 1 
dan Pasal 64. Hal itu dikarenakan Hak Cipta diperoleh secara otomatis setelah Ciptaan Logo diwujudkan dan diumumkan. ${ }^{18}$

\section{DAFTAR PUSTAKA}

\section{Buku}

Damian, Eddy. (2005). Hukum Hak Cipta Edisi Kedua Cetakan ke-3, Bandung: Alumni.

Djumhana, Ahmad \& R. Djubaedillah, (1993). Hak Milik Intelektual Sejarah, Teori $\mathcal{E}$ Prakteknya di Indonesia, Bandung: P.T. Citra Aditya Bakti.

Joachim Friedrich, Carl. (2014). Filsafat Hukum Perspektif Historis, Bandung: Nuansa dan Nusamedia.

Karjono, (2012). Perjanjian Lisensi Pengalihan Hak Cipta Program Komputer: Transaksi Elektronik, PT Alumni, Bandung.

\section{Jurnal}

Arfan, Hidayat. Dahlan. (2017). Perlindungan Hak Cipta Logo Berdasarkan UndangUndang Republik Indonesia Nomor 28 Tahun 2014 tentang Hak Cipta. Jurnal Ilmiah Mahasiswa Bidang Hukum Keperdataan. Universitas Syiah Kuala. Vol. 1(2) November 2017.

Dewi, Retasari. Preciosa Alnashava Janitra. Dramaturgi dalam Media Sosial: Second Account di Instagram Sebagai Alter Ego. Jurnal Fakultas Ilmu Komunikasi Universitas Padjadjaran.

Kurniawan, Denny. (2008). Perancangan Logo dan Maskot Untuk Mendukung Promosi Wisata Kuliner Malam Warung Tradisional di Surabaya. Jurusan Desain Komunikasi Visual, Fakultas Seni dan Desain. Surabaya: Universitas Kristen Petra.

Ngr Tian Marlionsa, A A. Ida Ayu Sukihana. (2018). Pelanggaran Hak Atas Kekayaan Intelektual dan Tuntutan Ganti Rugi Mengenai Hak Cipta Logo dari Pencipta. Jurnal Kertha Semaya. Vol. 6 No. 3.

Suparman, Eman. Renny Supriyatni. (2015). Perlindungan Hukum Kekayaan Intelektual Masyarakat Tradisional, Jurnal Pengabdian Kepada Masyarakat. Vol 2 No. 7.

\footnotetext{
18 Moh. Haris Lesmana. Logo dalam Hak Cipta. Opini Hukum. Accessed online from: https://rewangrencang.com/perlindungan-logo-dalam-hakcipta/\#: :text=Alasan\%20utama\%20mengapa\%20logo\%20tidak,tanda\%20yang\%20dapat\%20ditampilkan\%20secara [accessed November 11,2020].
} 
Tiara Hapsari, Faiza. (2012). Eksistensi Hak Moral dalam Hak Cipta di Indonesia. Universitas Diponegoro, Magister Ilmu Hukum. Jilid 41 No. 3.

Triyanto. (2020). Landasan Kerangka Filosofis HKI. FKIP Universitas Sebelas Maret. Jurnal Ilmiah Living Law. Vol 12 No 1 Tahun 2020.

Yanto, Oksidelfa. (2016). Konvensi Bern dan Perlindungan Hak Cipta. Jurnal Surya Kencana Dua: Dinamika Masalah Hukum dan Keadilan Vol. 6 No. 1 Maret 2016.

\section{Peraturan Perundang-Undangan}

Undang-Undang Dasar Negara Republik Indonesia Tahun 1945.

Undang-Undang Nomor 28 Tahun 2014 tentang Hak Cipta.

Undang-Undang Nomor 20 Tahun 2016 tentang Merek dan Indikasi Geografis.

\section{Sumber lainnya}

Amirulloh, Muhamad. Mendambakan Regulasi Paten Pendorong Kreativitas Karyawan Inventor di Indonesia, Seputar Jabar Online. Available online form: http:/ / www.seputarjabar.com/2015/10/mendambakan-regulasi-patenpendorong.html (accessed 05 September 2020).

Amrikasari, Risa. Prosedur Pendaftaran Logo Perusahaan. Hukumonline.com Available online form: https://www.hukumonline.com/klinik/detail/ulasan/lt577c8450a6db6/prosed ur-pendaftaran-logo-perusahaan/ (accessed 12 November 2020).

Haris, Moh. Lesmana. Logo dalam Hak Cipta. Opini Hukum. Available online form: https:// rewangrencang.com/perlindungan-logo-dalam-hakcipta/\#: :text=Alasan\%20utama\%20mengapa\%20logo \%20tidak,tanda \%20yang\% 20dapat\%20ditampilkan\%20secara (accessed 11 November 2020).

History of Copyright. Available online from: http://www.historyofcopyright.org/HistoryofCopyright/ (accessed 11 Oktober 2020). 